\title{
When Blackness Does Not Fade After a Pandemic: An Appeal to Acknowledge the Unequal Burden of Social Isolation
}

\author{
Nia Johnson $\mathbb{D}$
}

Published online: 13 June 2020

(C) The New York Academy of Medicine 2020

\begin{abstract}
Social distancing is one of the few tools that the everyman has to combat the Coronavirus disease. However, for those who are subject to racialized stereotypes about work productivity, educational ability, and other assumptions, the choice to socially distance can have many unintended consequences. This article is an appeal to our posterity, inviting a conversation about how we will remember the Coronavirus' impact on our lives. Will we selectively provide compassion for the racial groups we perceive more favorable when this is over? Or will we play favorites when it is time to pick up the pieces? This article provides scenarios and commentary on how social distancing could affect Black American populations - regardless of income or socioeconomic status. It argues that history has not been kind to Black Americans who have bought into mass national causes, and that there is an opportunity here to act differently.
\end{abstract}

As the Coronavirus disease ravages the world, families have cancelled weddings, countries have closed their borders, and the number of individuals applying for unemployment benefits have skyrocketed [1-3]. Though there is much unknown about the virus, one public health measure that is being recommended by the

N. Johnson $(\bowtie)$

Harvard University, Cambridge, MA, USA

e-mail: niajohnson@g.harvard.edu
Centers for Disease Control is containment through social distancing $[4,5]$. Though the Centers for Disease Control is recommending this for large groups and gatherings, there is a larger mass media discussion regarding the ethics of staying home [1,3]. Many are arguing that it one's duty to protect the immunocompromised and the elderly during this crisis and social distancing may be the only way to save lives in the face of a great unknown. However, this should also open the door to a thoughtful discussion about those who could reap the unintended consequences of social distancing after the virus has been slowed or mitigated. If the moral message passed on during this time continues to be that one should be willing to engage in social distancing as benevolent behavior, racially marginalized communities could be unmotivated to participate or have to reconcile with the consequences of forced participation due to the stigma that will follow them well after the pandemic has been addressed.

Suppose there are a Black employee and a White employee working at a largely populated company. Both have the same level of education, salary, and work experience. Both parties are also caring for elderly parents and have been given the option to socially distance themselves. The White employee chooses to socially distance themselves and work from home because their priority is to not harm the loved ones in their proximity. The Black employee has more to think about. They are concerned about the elderly, but they are also concerned about their broader community. The Black employee could socially distance themselves to protect their parent as a caretaker, but they are also concerned about their lack of visibility 
in the workplace contributing to negative stereotypes about Black individuals, such as stereotypes about laziness and sloth or having diminished productivity being attributed to their character [6-9]. This employee also knows that if they continue to go to work, it will put a loved one's life in danger. But they are also concerned that if an evaluation of their performance occurs within even six months after this crisis, the same benefit of the doubt that is given to another employee may not be afforded to them [10]. They could also be concerned that if their workplace reopens and they choose to stay home, that they could also incur harmful stereotypes about their work ethic. Both parties are concerned about their fellow man. However, the difference is that the perception of who is the most vulnerable is altered. Both parties' races create a special type of freedom and bondage - the White employee can engage with their sense of national pride and benevolence, freeing them from the concern of the consequences of that choice, while the Black employee is in bondage to that burden because of the potential consequences in the future.

Next, suppose there are two students who attend the same prestigious university. Both of the students are from unstable home environments and are required to return home to comply with social distancing policies. They return home to engage in remote classes, while also balancing the challenges of their home lives. Both students have a hard time retaining the information they learned in the remote classes. Both students are also given the opportunity to opt into a pass/fail system for their courses during this semester-leaving them with clean slates. They are able to return to school in the fall and start the next step of their programs. However, both start to struggle in classes because their deficiencies from the previous semester are on full display. The White student-rightfully understanding that they were victim to extenuating circumstances - goes to their professor, expresses that the Coronavirus threw them into an unstable environment and that is why they are not performing well in class. The Black student, however, feels ashamed and is concerned about the new stereotype threat that has crept into their educational experience $[6,9,10]$. They are aware that the professor could hold them to a different standard, in spite of the virus. But they also know that they have no chance at improvement if they do not speak up at all. Both are reaping very different consequences and burdens after it has passed.
What we actually see here are many short-sighted and worrisome assumptions - the assumption of shared ethics based on income, similar longterm goals, and a shared sense of community benevolence. For the White employee, they could socially isolate themselves and bear the consequences of limited social interactions while aiding their country or choose to not socially isolate themselves and incur some broader societal shaming. For the White, economically disadvantaged student, they have the opportunity to freely call back to the Coronavirus as a time of hardship for their academics, with minimal fear of stereotype threat and almost assured benefit of the doubt. However, for the Black employee and student, they may actually be in a lose-lose situation. They could socially isolate themselves, but could incur unforeseen consequences on themselves, their families, or a future Black employee or student. The employee could choose to not socially isolate themselves, and incur the risk of being perceived as callous to the needs of the present vulnerable people in their lives-while also carrying the aforementioned consequences. For the student, they could be perceived as unproductive if they ask for help. If they call back to the Coronavirus, they could be viewed as insensitive for calling back to a national crisis as their academic undoing. But if they say nothing, they will not get the help that they need. And where does that leave their choice?

Often it is easy to forget that the American relationship with race and prejudice has long-term consequences that most did not expect. When the USA codified the unequal treatment of Black Americans, profiled the group as lacking in moral character, and systemically disenfranchised them, one could not have thought that there would be an instance where we need the entire nation to be motivated to socially isolate themselves as a way to protect the greater good. However, a consequence of the unethical treatment of Black Americans is the creation of two greater goods. There is the greater good of benevolence to a more mainstream, majority society and a greater good for a society that understands that when this has all ended, they still will have to live under unfair conditions. In this case, Whiteness has created and provided the freedom to worry about the immediate circumstances at hand. However, Blackness has been subjugated into a duality of priorities. They are not just worried about protecting the elderly, the immunocompromised, and themselves. They are worried about protecting their own elderly, immunocompromised, 
children, families, and broader communities - not only from the Coronavirus but also from life afterwards.

We have to free everyone to participate in the best health practices for this crisis, without saddling them with the consequences of stereotyping and unconscious bias. This starts with understanding how deeply racially marginalized groups understand and move in the face of oppression. It is not enough to just absorb that the United States has a racist past. This is also not just about combating Coronavirus disease. This is an extension of the general stresses of being a Black individual in the United States. This cognitive calculus that Black Americans do on a regular basis just happen to intertwine with new social expectations of how we protect ourselves and those vulnerable to illness. We need to be willing to examine our biases well before this crisis is over. Will we have selective memories about the impact of Coronavirus disease when it is time to evaluate workplace promotions or educational progress? Or will we actually commit to affording everyone a global pass?

For some, the option to socially isolate may seem like the most moral and responsible choice. But this choice is nuanced, and may require a larger sacrifice from racially marginalized populations. What is interesting is that some forums have referred to fighting the Coronavirus disease as analogous to needing a "wartime-like willingness to cooperate." What we also know is that even when Black Americans have engaged in a wartime-like willingness to cooperate - gladly and willingly entering literal wars on the behalf of the United States - they were shunned when the crisis was over [11]. History has consistently shown that compliance does not always bear fruit for racially marginalized groups. This is not advocating for lack of sacrifice- social distancing $r e$ quires sacrifice to protect those who are at risk for contracting Coronavirus disease. However, this is a call to remember that sacrifice has come at a larger expense for some more than others. And when this inevitably ends, and business as usual resumes, that should be remembered.

Acknowledgments A special thank you to Lance Wahlert, $\mathrm{PhD}$, Yolonda Wilson, $\mathrm{PhD}$, and Donna Castelblanco, MBE, for their thoughtful and insightful comments.

\section{References}

1. Mounk Y. Cancel Everything. The Atlantic. Published March 10, 2020. https://www.theatlantic. com/ideas/archive/2020/03/coronavirus-canceleverything/607675/. Accessed 11 March 2020.

2. To fight coronavirus spread, U.S. may expand "social distancing" measures. STAT. Published February 3, 2020. https://www.statnews.com/2020/02/03/coronavirus-spreadsocial-distancing-us/. Accessed 11 March 2020.

3. Brooks M. Opinion | Social distancing may be our best weapon to fight the Coronavirus. The New York Times. Published March 11, 2020. https://www.nytimes.com/2020 /03/11/opinion/coronavirus-prevention-distancing.html. Accessed 11 March 2020.

4. Threats I of M (US) F on M. Strategies for disease containment. National Academies Press (US); 2007. https://www. ncbi.nlm.nih.gov/books/NBK54163/. Accessed March 11, 2020 .

5. Implementation of mitigation strategies for communities with local COVID-19 transmission. :10.

6. Nadler DR, Komarraju M. Negating stereotype threat: autonomy support and academic identification boost performance of African American college students. J Coll Stud Dev. 2016;57(6):667. https://doi.org/10.1353 /csd.2016.0039.

7. Craemer T, Orey D. Implicit Black identification and stereotype threat among African American students. Soc Sci Res. 2017;65:163-180. https://doi.org/10.1016/j. ssresearch.2017.02.003.

8. DeCuir-Gunby JT, Gunby NW. Racial microaggressions in the workplace: a critical race analysis of the experiences of African American educators. Urban Educ. 2016;51(4):390414. https://doi.org/10.1177/0042085916628610.

9. Johnson TT. The impact of negative stereotypes \&amp; representations of African-Americans in the media and African-American incarceration. Published online 2012. https://escholarship.org/uc/item/8xm9j2kf. Accessed 11 March 2020.

10. What Is White Privilege, Really? Teaching Tolerance. Published August 15, 2018. https://www.tolerance. org/magazine/fall-2018/what-is-white-privilege-really. Accessed 13 March 2020.

11. Baker PC. The Tragic, Forgotten history of black military veterans. The New Yorker. https://www.newyorker. com/news/news-desk/the-tragic-forgotten-history-of-blackmilitary-veterans. Accessed 22 May 2020.

Publisher's Note Springer Nature remains neutral with regard to jurisdictional claims in published maps and institutional affiliations. 